TOURAJ DARYAEE

University of California, Irvine

e-mail: tdaryaee@uci.edu

\title{
Honey: A Demonic Food in Zoroastrian Iran?
}

\begin{abstract}
This paper discusses bees as noxious creatures in the Zoroastrian animal classification system and the problem of honey for consumption in the Iranian world. The mention of honey as the production of evil being not only appears in Zoroastrian literature, but also in early Persian histories where primordial king Tahmures is hand this beneficial product for use. The name of the demons in this Persian text associated with honey suggests a long tradition of association of honey with the daivas or fallen gods of the ancient Iranian world. Eventually, in the early Islamic period honey was allowed for use, but with certain restrictions.
\end{abstract}

Keywords: angubēn, honey, daiva, Tahmures

It is fascinating that throughout Zoroastrian writings and the ancient Iranian mythological tradition the bee and honey are seen to belong to the realm of the demonic. In this essay in honor of my colleague, Anna Krasnowolska I would like to explore the reasons for which the use of honey was prohibited in the Zoroastrian tradition. ${ }^{1}$ This demonic nature of the animal and its byproduct can be recognized from the medieval Persian text, Zainu'l-Akhbār of Gardīzī. The first part of the book which deals with the Persianate world, the arts, skills and actions of the primordial kings are listed. For Tahmures, we come across a very interesting tradition which is not found in most other sources. The king is said to have fought demons (dēwān) and kept them from harming people and caught them and killed many. The demons came before him and asked till when they will have such misfortune at the king's hands. Tahmures provides a very interesting response. He states that till that time when the dry wood and dry string come to speak and till the tree brings forth kingly dress and till he holds the wind in my fists and when he eats food well which has not been made from harming the cow and not cooked with fire. Then the demons bring forth the tanbūr, the silkworm and:

${ }^{1}$ H. A‘lam, Honey, [in:] Encyclopaedia Iranica, ed. E. Yarshater, online edition 2012, http://www. iranicaonline.org/articles/honey-asal (access: 17.06.2019). 
The bees made honey and they said: Now there will be good food which is made without harming the cow and not cooked with fire. ${ }^{2}$

The demons are also named in the text: Haštom, Adādrā and Vantū. I would hazard a guess that the second demon may be Indra, whose Middle Persian for Andar ('ndr), may have been miswritten due to orthographical mistakes between the Aramaic and the Perso-Arabic script. It is still difficult to match these three names with the fallen gods (Daivas), from the time of the Indo-Iranian tradition, namely Saurwa, Indra and NånhaiӨya, but there seems to be some connections here which may be a residual of a long tradition.

In the Zoroastrian animal classification, there is a clear duality which matches the world-view of this religious tradition, where they either belong to the realm of Ohrmazd or Ahriman. ${ }^{3}$ In the classification of xrafstars or noxious creatures, the Bundahišn divides them into three categories:

\section{hamāg xrafsatarān sē èwēnag hēnd ābìg ud zamīgìg ud parragīg. ${ }^{4}$}

All the noxious creatures are of three sorts: aquatic, earthly and winged.

The honey bee magas $\bar{l}$ angubēn belongs to the category of winged xrafstars or noxious creatures, but there is a twist here where the commentators of the text state that Ohrmazd through its infinite wisdom turned some of the xrafsatars to bring benefit, including:

magas kē angubèn kunēd ud kirm kē abrēšom. ${ }^{5}$

The fly which makes honey and the worm which (makes) silk.

This passage is most curious and suggests the uneasiness with which the Zoroastrians saw the benefits of bees and honey. This Zoroastrian world-view in late antiquity becomes more manifest when looking at cooking and food preparation. ${ }^{6}$ In the only surviving Middle Persian text, Xusro ud Rédag (Khusro and the Page), ${ }^{7}$ which can be dated to the $6^{\text {th }}$ century CE, we have a wonderful list of the meats, deserts and wines and their method of preparations. The king's table in this text exhibits the power and economic reach of the Sasanian world in late antiquity. Chinese and Indian fruits and goods to Roman and Near Eastern wines and delicacies are all mentioned. What is striking in this text is the absence of the use of

${ }^{2}$ Gardīzī, Zainu'l-Akhbār, ed. R. Rezazadeh Malek, Tehran 2005, p. 66.

${ }^{3}$ On the study of animal classification in Zoroastrianism where the species are divided into five categories see H.-P. Schmidt, Ancient Iranian Animal Classification, "Studien Zur Indologie und Iranistik" 1980, vol. 5-6, no. 190, pp. 209-244; Schmidt by going through the sources, namely the Avesta, the Bundahišn and the Zädsparam, does not see a unified system, nor does he advocate Greek or Indian influence. See also M. Moazami, Evil Animals in the Zoroastrian Religion, "History of Religions" 2005, vol. 44, no. 4, pp. 300-317.

${ }^{4}$ Bundahišn, 22.8, F. Pakzad, Bundahišn: Zoroastrische Kosmogonie und Kosmologie, Bd. 1, Tehran 2005, p. 257.

${ }^{5}$ Bundahišn, 22.29, Pakzad, op. cit., p. 262.

${ }^{6}$ For a survey of cooking see J. Amouzegar, Cooking ii. In Pahlavi Literature, [in:] Encyclopaedia Iranica, ed. E. Yarshater, online edition 2011, http://www.iranicaonline.org/articles/cooking\#pt2 (access: 17.06.2019).

${ }^{7}$ Husraw ì Kawādān ud Rēdag-ē, ed. and trans. S. Azarnouche, Khosrow fils de Kawād et un page, "Studia Iranica", Cahier 49, Paris 2013. 
honey for any purpose, as if the Iranians were unfamiliar with it. If we take into consideration the demonic nature of the producer of this food, however much the Bundahišn emphasizes Ohrmazd's work in turning its nature, we can understand the absence of honey in the Zoroastrian Middle Persian texts. There is only one other Middle Persian text where there is a mention of honey and that is the Draxt $\bar{\imath} \bar{A} \operatorname{su} \bar{r} \bar{g}$ (Assyrian Tree). Here the mention of the honey and bee is given as such, where the palm tree is stating its benefits to the goat says:

š̀ir hèm warzīgarān angubēn āzādmardān. ${ }^{8}$

My milk is for the peasants, honey for the nobles

In lieu of the discussion of the Xusro ud Rédag, then the question arises as to why its absence in the late Sasanian text and its association with the nobility in the Draxt $\bar{\imath} \bar{A} \operatorname{su} r \bar{l} g$ ? The reason for the inclusion of honey here may exhibit the ancient Mesopotamian tradition of this text. ${ }^{9}$ Furthermore, the Draxt $\bar{\imath} \bar{A} s \bar{u} r \bar{g} g$ was composed in the Parthian period which predates the codification of animal classification in the Sasanian period and in its nature is a secular text devoid of late antique religiosity. ${ }^{10}$ Hence, its inclusion is possible because it predates the Zoroastrian didactics in late antiquity. It is curious that from the Parthian period, Strabo makes an observation where honey is again used, this time by the Magi in making sacrifice to the waters. Strabo states (XV.III.14):

They sacrifice to water by going to a lake, river, or fountains; having dug a pit, / they slaughter the victim over it, taking care that none of the pure water near be / sprinkled with blood, and thus be polluted. They then lay the flesh in order upon / myrtle or laurel branches; the Magi touch it with slender twigs and make incantations, pouring oil mixed with milk and honey, not into the fire, nor into the water, but / upon the earth. They continue their incantations for a long time, holding in the / hand a bundle of slender myrtle rods. ${ }^{11}$

I should finally touch upon another "demonic" association between honey and Zoroastrianism. In the Zoroastrian tradition the three important or arch-demons are mentioned: Indra (Ved. Índra / MP Andar), Sauruua (Ved. Śarvá / MP Sāwul),

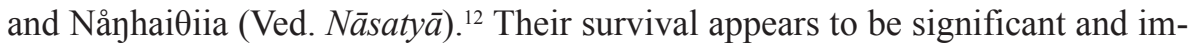
portant and the reasoning for their appearance in the Wìdêwdād is unclear ${ }^{13}$ Herrenschmidt \& Kelllens states that it is remarkable that the authors of the Wìdēwdäd have a memory of these Indo-Iranian gods and to have demonized them later. The Nāsatyā are identified with the Ašvins who in the Vedic tradition are benevolent and who are invoked in the Vedic tradition more than any other gods, with the exception of Indra, Agni and Soma. The Ašvins have one characteristic which

${ }^{8}$ Draxt $\bar{\imath} \bar{A} \operatorname{s} \bar{r} \bar{r} g$ 19, ed. and trans. M. Navvābi, Manzūme-ye Draxt $\bar{l} \bar{A} \operatorname{sū} r \bar{g} g$, Tehran 1967, pp. 48-49.

9 S. Smith, Notes on 'The Assyrian Tree', "Bulletin of the School of Oriental and African Studies" 1926-1928, vol. 4, pp. 69-76.

${ }^{10}$ M. Macuch, Pahlavi Literature, [in:] The Literature of Pre-Islamic Iran, eds. R.E. Emmerick, M. Macuch, London-New York 2009, pp. 170-171.

${ }_{11}$ The Geography of Strabo, trans. H.C. Hamilton, W. Falconer, vol. 3, London 1889, pp. 136-137.

12 Wìdêwdād 10.9, see M. Moazami, Wrestling with the Demons of the Pahlavi Widēwdād, Leiden-Boston 2014, pp. 298-299.

${ }_{13}^{13}$ C. Herrenschmidt, J. Kelllens, Daiva, [in:] Encyclopaedia Iranica, ed. E. Yarshater, online edition 2001, http://www.iranicaonline.org/articles/daiva-old-iranian-noun (access: 17.06.2019). 
concerns us here and that is their connection with honey (mádhu). They are filled with honey, but more importantly are the ones who gave honey to the bees. ${ }^{14}$ One cannot state that the reason for which the Ašvins became the fallen gods in Zoroastrianism is due to their association with primarily honey, but as the Wìdêwdād

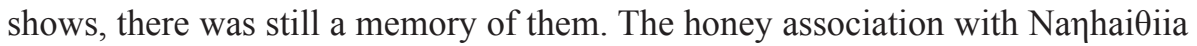
is yet another nail in the coffin of our Indo-Iranian fallen gods whose reasoning for demotion in the Zoroastrian world is unclear. ${ }^{15}$ In the Zoroastrian tradition

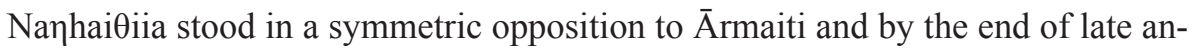
tiquity was still remembered as an arch-daiva.

It should be mentioned that with the coming of Islam and its positive view honey, the Zoroastrians were to have a rethinking of the use of honey. In the medieval theological discussions, honey became a subject of interest as Jews, Christians and Muslims all used it for food and medicinal purposes and not doubt the lay Zoroastrians were exposed. The Zoroastrians in the medieval period had accepted the fact that honey could and should be consumed, but ruling was that it could not begotten from a non-Zoroastrian, but rather should be purchased from the Wehden.${ }^{16}$ The story of Zoroastrians landing in India in the $10^{\text {th }}$ century and their meeting with the local king Jadhav Rana is interesting for many reasons. One note related to our study is the question and answer session between the Jadhav Rana and the four Zoroastrian priests. The Indian king asks what will the Zoroastrians do for his country in return to being allowed to stay? They Zoroastrian priests answered by taking the following action:

The old priest asked for a brass bowl to be filled with milk and brought to / the assembly. He then stirred a spoonful of sugar in the bowl and holding it / up in his trembling hands asked: 'Does any many see the sugar in the bowl / of milk?' All shook their heads. 'Sire, said the priest, we shall try to be like / this insignificant amount of sugar in the milk of your human kindness. ${ }^{17}$

The Zoroastrians had finally arrived at a safe land, a sort of promise land. However, this promise land was not the land of milk and honey, as honey was not a heavenly food, rather a demonic food from a demonic creature. So while those following the Abrahamic tradition took to honey and specifically in Judaism, the land of "milk and honey", (Canaan) became an important metaphor, in Zoroastrianism it was "milk and sugar", that had to give birth to the narrative of the Parsi migration to India.

14 A.A. Macdonell, A Vedic Reader for Students, Oxford 1917, pp. 128-129.

${ }_{15}$ For a early study of the issue see G. Dumézil, Naissance d'Archanges (Jupiter Mars Quirinus, III). Essai sure la formation de la théologie zoroastrienne, Paris 1945, p. 92. For the latest remark see É. Pirart, Georges Dumézil face aux demons Iraniens, Paris 2007, p. 43, 83.

${ }^{16}$ The Persian Rivayats of Hormazyar Framarz and others, trans. B.N. Dhabhar, Bombay 1932, pp. 265-266.

${ }_{17}$ S. Taraporevala, Parsis: The Zoroastrians of India. A Photographic Journey 1980-2004, Woodstock-New York-London 2004, p. 15. 


\section{Bibliography}

A'lam H., Honey, [in:] Encyclopaedia Iranica, ed. E. Yarshater, online edition 2012, http://www.iranicaonline.org/articles/honey-asal (access: 17.06.2019).

Amouzegar J., Cooking ii. In Pahlavi Literature, [in:] Encyclopaedia Iranica, ed. E. Yarshater, online edition 2011, http://www.iranicaonline.org/articles/cooking\#pt2 (access: 17.06.2019).

Azarnouche S., Khosrow fils de Kawād et un page, "Studia Iranica", Cahier 49, Paris 2013.

Dumézil G., Naissance d'Archanges (Jupiter Mars Quirinus, III). Essai sure la formation de la théologie zoroastrienne, Paris 1945.

Gardīzī, Zainu'l-Akhbār, ed. R. Rezazadeh Malek, Tehran 2005.

Herrenschmidt C., Kelllens J., Daiva, [in:] Encyclopaedia Iranica, ed. E. Yarshater, online edition 2001, http://www.iranicaonline.org/articles/daiva-old-iranian-noun (access: 17.06.2019).

Macdonell A.A., A Vedic Reader for Students, Oxford 1917.

Macuch M., Pahlavi Literature, [in:] The Literature of Pre-Islamic Iran, eds. R.E. Emmerick, M. Macuch, London-New York 2009.

Moazami M., Evil Animals in the Zoroastrian Religion, "History of Religions" 2005, vol. 44 , no. 4.

Moazami M., Wrestling with the Demons of the Pahlavi Widēwdād, Leiden-Boston 2014.

Navvābi M., Manzūme-ye Draxt ī Āsūrīg, Tehran 1967.

Pakzad F., Bundahišn: Zoroastrische Kosmogonie und Kosmologie, Bd. 1, Tehran 2005.

Pirart É., Georges Dumézil face aux demons Iraniens, Paris 2007.

Schmidt H.-P., Ancient Iranian Animal Classification, "Studien Zur Indologie und Iranistik" 1980, vol. 5-6, no. 190, pp. 209-244.

Smith S., Notes on 'The Assyrian Tree', "Bulletin of the School of Oriental and African Studies" 1926-1928, vol. 4, pp. 69-76.

The Geography of Strabo, trans. H.C. Hamilton, W. Falconer, vol. 3, London 1889.

The Persian Rivayats of Hormazyar Framarz and others, trans. B.N. Dhabhar, Bombay 1932.

Taraporevala S., Parsis: The Zoroastrians of India. A Photographic Journey 19802004, Woodstock-New York-London 2004. 